\title{
The Hospitality Phenomenon: Philosophical EnLightenMent?
}

\author{
Kevin D O'Gorman \\ Department of Hospitality and Tourism Management \\ The University of Strathclyde \\ Curran Building \\ 94 Cathedral Street \\ Glasgow G4 OLD
}

00441415483941

kevin.ogorman@strath.ac.uk

\begin{abstract}
Purpose - The emergent paradigm of hospitality studies does not have a coherent philosophical foundation. In seeking to identify a philosophy of hospitality this paper explores Derrida's contribution, along with other writers in philosophy and postcolonial theory, who are either writing in the field or have developed his works.
\end{abstract}

Design/methodology/approach - Derrida and others are often cited within the context of the emerging paradigm of hospitality studies. In order to examine and critically evaluate the possibility of the construct of a philosophy of the phenomenon of hospitality, the review of the philosophical concepts is set within three perspectives: individual moral philosophy; hospitality and the nation states, and hospitality and language.

Findings - Although examining the writings of Derrida and others provides an insight into the phenomenon of hospitality, a coherent philosophy of hospitality seems to be an enigma; possibly because hospitality is not a matter of objective knowledge.

Research limitations/implications - In order to inform the emergent paradigm of hospitality studies there needs to be a continuing multi-disciplinary study of hospitality; further inter and intra disciplinary research and investigation is required.

Originality/value - The paper illustrates that critical analysis is more important than the unquestioning acceptance of the views of philosophical theorists.

Keywords Hospitality services, Hospitality management, Philosophical concepts Paper type Conceptual paper 


\section{INTRODUCTION}

Since the publication of 'In Search of Hospitality: Theoretical Perspectives and

Debates' (Lashley and Morrison eds., 2000), there has been an increasingly wideranging interdisciplinary perspective to the exploration of the concept of hospitality. Morrison (2004:4) asserts that there is already considerable justification for the study of hospitality as "a core cultural and social concept in higher education" and supports this by citing various authors as advocates of this approach. Lashley (2004: 13) succinctly sums up the debate up as follows: "the study of hospitality allows for a general broad spectrum of enquiry, and the study for allows studies that support the management of hospitality" (Lashley 2004: 15).

Morrison and O'Gorman (2006:4) note that Lashley's statement explicitly acknowledges that the intellectual growth and progression of hospitality as an academic field of study is best served through the critical analysis of the concept of hospitality as broadly conceived.

"Academic reputation can be enhanced through the celebration of its diversity and multi-disciplinarity as a specialist field of study, with systematic, vibrant partnering and intellectual exchange of hospitality and of discipline-based academics, unfettered by artificially created boundaries that serve to isolate and perpetuate an insularity in the process of knowledge creation and higher education"

Hospitality is no longer only considered synonymous with hospitality management and the hospitality industry. The phenomenon of hospitality is becoming a recognised field of study. This has been further supported with the publication of Hospitality: A social lens Lashley, Lynch and Morrison (eds) (2007) argue that hospitality research has gained a more multidisciplinary perspective. 
Despite this wider study of the phenomenon of hospitality, although a clear and coherent philosophy of hospitality has not yet been proposed, the writings of Jacques Derrida on hospitality have been influential. Derrida's writings have had an impact on a wide range of disciplines and areas of study, including education, gender, law, literature, mathematics, politics, psychology, race and theology. This paper explores Derrida's contribution to the philosophy of hospitality, picking up on some other writers in philosophy and postcolonial theory who are either writing in the field or have developed his writing. After a short biography, the paper focuses on three Tseparate issues: moral philosophy of hospitality from the perspective of the guest host relationship; hospitality between peoples and nation states; and the use of language in hospitality provision and consumption.

\section{WHO WAS DERRIDA?}

The office of the President of France announced the death Jacques Derrida in 2004, saying "in him France gave the world one of the major figures of the intellectual life of our times." Internationally, Deutscher (2005) notes that Derrida was widely considered the most important French philosopher of the late twentieth century; he was also the subject of three films and a number of media controversies. Derrida was credited as the inventor of 'deconstruction,' the practice of dismantling texts by revealing their assumptions and contradictions. Normally life is lived at the level where things are presumed, people are accustomed to think in narrow ways. Deconstruction attempts to highlight just how much is taken for granted in contemporary conceptual thought and language. In 1967, Derrida's international reputation had been secured by the publication of three books (Derrida 1973, 1976, 1978), and he went on to publish 40 different works. 
Derrida grew up as a Jew in Algeria in the 1940s, during and after the anti-Semitic French colonial regime. He had been excluded in his youth from his school after it had reduced the quotas for Jews. Confronted with violent racism, he avoided school during the period when he was obliged to attend a school for Jewish students and teachers. He eventually managed to gain entry to study philosophy in Paris at the École Normale Supérieuri. However Deutscher (2005:10) records that "his subsequent experiences as a young student in Paris were isolated and unhappy, consisting of intermittent depression, nervous anxiety and a seesaw between sleeping tablets and amphetamines resulted in exam failures in the early 1950's." He then studied in University of Louvain in Belgium where he wrote his thesis on Husserl (Derrida 2003); later taught at the Sorbonne, and then returned to the École Normale Supérieur as a lecturer. In 1983, Stocker (2006) records that Derrida became the founding director of the Collège International de Philosophie, where open lecture courses were given by a volunteer body of philosophers.

Various philosophers have tried to attach different labels to him: a pragmatist (Rorty 1982); a post-Kantian transcendentalist (Gasché 1986); and a linguistic philosopher (Norris 1987) showing the difficulty in locating deconstructionalism within philosophy, let alone an academic discipline. As well as being one of the most cited modern scholars in the humanities, he was undoubtedly one of the most controversial. In 1992 a proposal to award him an honorary doctorate at Cambridge University caused such uproar that, for the first time in 30 years, the university was forced to put the matter to a ballot; with the degree only being awarded by a majority vote. 
From various biographies and obituaries, it is clear that Derrida was undoubtedly a controversial character; his dramatic early failures were contrasted by the outstanding successes in later life. His work advanced the deconstruction of "the very concepts of knowledge and truth,' and provoked strong feelings within his readers who, just like the Senate of Cambridge University, are often divided over his writings, considering them to be either on the one hand absurd, vapid and pernicious or on the other hand logical, momentous and lively

\section{INDIVIDUAL MORAL PHILOSOPHY: HOST}

Derrida (2000a) defined hospitality as inviting and welcoming the 'stranger'. This takes place on different levels: the personal level where the 'stranger' is welcomed into the home; and at the level of individual countries. His interest was heightened by the etymology of Benveniste (1969) who analysed 'hospitality', as being from a Latin root, but derived from two proto Indo-European words that have the meanings of 'stranger', 'guest' and 'power'. Thus in the 'destruction' of the word, there can be seen:

"an essential 'self limitation' built right into the idea of hospitality, which preserves the distance between one's own and the 'stranger', between owning one's own property and inviting the 'other' into one's home" (Caputo 2002:110).

So, as Derrida (2000a:13) observed there is always a little hostility in all hosting and hospitality, constituting what he called a certain 'hostipitality': "If I say 'Welcome', I am not renouncing my mastery, something that becomes transparent in people whose hospitality is a way of showing off how much they own or who make their guests uncomfortable and afraid to touch a thing." To Derrida then, the notion of having and retaining the mastery of the house underlies hospitality. 
“"Make yourself at home', this is a self-limiting invitation... it means: please feel at home, act as if you were at home, but, remember, that is not true, this is not your home but mine, and you are expected to respect my property" (Caputo 2002:111).

Telfer (2000) also explores this issue when discussing the motivation behind hospitality. There is a limitation to the amount of hospitality that 'hosts' can and wish to offer, just as important are the intentions that that lie behind any hospitable act: there surely is a distinction to be made between hospitality for pleasure and hospitality that is born out of a sense of duty. She considers hospitality to be a moral virtue, and articulates hospitable motives to be:

"those in which concern for the guests' pleasure and welfare, for its own sake, is predominant. These can include entertaining for pleasure where that pleasure largely depends on knowing that one is pleasing the guests, and sense of duty where there is also concern for the guests themselves. And hospitable people, those who possess the trait of hospitableness, are those who often entertain from one or more of these motives, or from mixed motives in which one of these motives is predominant." (Telfer 1996:82)

People choose to pursue the virtue of hospitableness because they are attracted by an ideal of hospitality, as Telfer (1996:101) "The ideal of hospitality, like all ideals, presents itself as joyful rather than onerous, and provides the inspiration for the pursuit of the virtue or virtues of hospitableness." There is a distinction made between hospitality offered for pleasure and hospitality that is born out of a sense of duty. Telfer (1996) also develops this classification to include the type of guest to whom a host would offer hospitality. This classification is summarised as:

1. Those in a relationship to the host. This includes guests within a social circle, that the host is obliged to offer hospitality to, e.g. colleagues, neighbours, fellow parishioners, parents whose children are friends and relatives.

2. Those in need. This Telfer (1996:91f) terms "good-Samaritan hospitality", this encapsulates all who are in need of hospitality. It may be a need for food and drink, however it also includes "a psychological need of a kind which can be met particularly well by hospitality, such as loneliness or the need to feel valued as an individual." 
3. Friends of the host. Hospitality is shown to friends because "liking and affection are inherent in friendship; the liking produces a wish for the friends' company (as distinct from company in general), the affection a desire to please them" (Telfer 1996:93)

On several occasions Telfer (1996) arguments are based on simple assertions rather than an elaboration of philosophical underpinnings, or on the use of descriptive categories as universals of human conduct. For example, Telfer (1996: 107) notes gluttony may come in several forms but always involves "caring too much for the pleasures of eating and drinking"; this seems to be a rather sweeping statement to cover all of human society.

Telfer (1996:93) argues that there is a special link between friendship and hospitality, because it involves the home of the host: "hospitality (provided it is not too formal) is an invitation to intimacy, an offer of a share in the host's private life." This can cause a paradox when the friends start visiting without invitation and therefore they stop being guests and start to become like part of the family. Telfer (1996:93) then asks "Is turning friends into family the essence of this kind of hospitality, or does it go beyond hospitality?" Hospitality in this situation is double edged: the host can either make a special fuss over them or the special fuss can be deliberately avoided to allow them to feel at home. Telfer (1996:101) concludes that the reason why hosts choose to pursue the virtue of hospitableness is that they are attracted by an ideal of hospitality. "The ideal of hospitality, like all ideals, presents itself as joyful rather than onerous, and provides the inspiration for the pursuit of the virtue or virtues of hospitableness."

In stark contrast to the individualistic perspective offered by Telfer on hospitality in a domestic context, Derrida (2000b), offers a more encompassing philosophy of 
hospitality. In an attempt to clarify terminology, this section adopts Derrida's differentiation between the 'law of hospitality' and 'laws of hospitality':

\begin{abstract}
"The law of unlimited hospitality (to give the new arrival all of one's home and oneself, to give him or her one's own, our own, without asking a name, or compensation, or the fulfilment of even the smallest condition), and on the other hand, the laws (in the plural), those rights and duties that are always conditioned and conditional, as they are defined by the Greco-Roman tradition and even the Judaeo-Christian one, by all of law and all philosophy of law up to Kant and Hegel in particular, across the family, civil society, and the State" (Derrida 2000b:77).
\end{abstract}

This distinction is useful because clarifies that there is a universal truth of hospitality, however the way that hospitality is offered is normally governed by a set of man made rules dependent on the context: domestic, civic or commercial.

In his discussions Derrida (2000b), makes a distinction between unconditional hospitality, which he considers impossible, and hospitality that is always conditional. A distinctive aspect of Derrida's approach to the phenomenon of hospitality is his reflection on how achieving an absolute hospitality is impossible. In trying to imagine the extremes of a hospitality to which no conditions are set, there is a realisation that unconditional hospitality could never be accomplished. It is not so much an ideal: it is an impossible ideal. The phenomenon of hospitality necessarily contains the concept of the other or foreigner within it, since hospitality requires, $a$ priori, a concept of the outsider or guest. From the perspective of the host, Derrida distinguishes between a guest and a parasite:

"In principle, the difference is straightforward, but for that you need a law; hospitality, reception, the welcome offered have to be submitted to a basic and limiting jurisdiction. Not all new arrivals are received as guests if they don't have the benefit of the right to hospitality or the right of asylum, etc. Without this right, a new arrival can only be introduced 'in my home,' in the host's 'at 
home,' as a parasite, a guest who is wrong, illegitimate, clandestine, liable to expulsion or arrest" (Derrida 2000b:59f.)

Derrida (2000b) argues that hospitality is therefore conditional in the sense that the outsider or foreigner has to meet the criteria of the a priori 'other'. He is implying that hospitality is not given to a guest that is absolutely unknown or anonymous, because the host has no idea of how they will respond.

"Absolute hospitality requires that I open up my home and that I give not only to the foreigner (provided with a family name, with the social status of being a foreigner, etc.), but to the absolute, unknown, anonymous other, and that I give place to them, that I let them come, that I let them arrive, and take place in the place I offer them, without asking of them either reciprocity (entering into a pact) or even their names. The law of absolute hospitality commands a break with hospitality by right, with law or justice as rights" (2000b: 25)

Derrida (1999a) observes that absolute hospitality requires the host to allow the guest to behave as they wish; there must be no pressure or obligation to behave in any particular manner. Absolute hospitality does not make a demand of the guest that would force them to reciprocate by way of imposing an obligation. The language used by Derrida could be held to imply that make a guest conform to any rules or norms is a bad thing.

\section{HoSPITALITY AND THE NATION STATES}

As well as the guest host relationship at the individual level, the relationship can also exists on a wider scale: hospitality between peoples and states. By using the illustrative example of the French Revolution and the declaration of national hospitality as providing a case example of hospitality offered by the states. Immanuel Kant argued that individuals had a universal right to shelter in any country, but for a limited time period and not if they would jeopardize the security of the country in 
question. This philosophy was codified in French national hospitality during the revolution when 1793 Saint-Just in the Essai de Constitution stated:

"The French people declares itself to be the friend of all peoples; it will religiously respect treaties and flags; it offers asylum in its harbours to ships from all over the world; it offers asylum to great men and virtuous unfortunates of all countries; its ships at sea will protect foreign ships against storms. Foreigners and their customs will be respected in its bosom." (Duval 1984: 441)

This quote illustrates the original rhetorical gestures used to present the French Republic as generous and hospitable; the promise a generous and welcoming attitude to all strangers.

When reviewing French revolutionary hospitality, Wahnich (1997a: 346) identifies that its raison d'être was in offering sanctuary and security to all: "first and foremost, citizens are men, and the purpose of national law is not to identify the frontier but to guarantee universal law, without limits." However as soon as this principle of hospitality was established it was betrayed. Wahnich (1997a:347) asserts that "the enigma of a hospitality subverted by suspicion, of friendship experienced in terms of treason, and of a fraternity that invents the most radical forms of exclusion." Wahnich (1997b) also highlights a modern hospitality enigma: the situation where nation states want their emigrants treated as sacred guests but pay scant attention to their own laws of hospitality regarding immigrants. In contemporary times, nations admit a certain number of immigrants - conditionally. This is echoed in the writings of Schérer (1993:7) registering his concern that hospitality has become an impossible luxury:

"Isn't hospitality the madness of our contemporary world? To praise hospitality just when, in France and almost everywhere else in the world, the main concern is to restrict it, from the right to asylum to the code of 
nationality! Disturbing, excessive, like madness, it resists all forms of reason, including raison d'être."

Studying hospitality and the nation states, Derrida (1999a) notes that to the best of his knowledge there is no country in the world that allows unconditional immigration. Individuals may consider themselves to be practically hospitable, however they will not leave their doors open to all who might come, to take or do anything, without condition or limit. Derrida argues the same can be said about nation states; conditional hospitality takes place only in the shadow of the impossibility of the ideal version. Derrida (1998b:70) reflects on the conceptual possibility of unconditional hospitality in order "to understand and to inform what is going on today in our world". This is reflected in the following quote:

"Unconditional hospitality implies that you don't ask the other, the newcomer, the guest to give anything back, or even to identify himself or herself. Even if the other deprives you of your mastery or your home, you have to accept this. It is terrible to accept this, but that is the condition of unconditional hospitality: that you give up the mastery of your space, your home, your nation. It is unbearable. If, however, there is pure hospitality, it should be pushed to this extreme" (Derrida 1998b:71).

Derrida (1998b:70) also questions the restricted nature of national hospitality to legal and illegal immigrants:

"We know that there are numerous what we call 'displaced persons' who are applying for the right to asylum without being citizens, without being identified as citizens. It is not for speculative or ethical reasons that I am interested in unconditional hospitality, but in order to understand and to transform what is going on today in our world."

In Derrida's later works, he is interested in many unconditionals: such as an unconditional gift, an unconditional pardon and an unconditional mourning. As each of these is deemed impossible, impossibility takes on an increasingly strong resonance 
in his late work. Derrida's views on hospitality illuminate a transition in his philosophical project from earlier writings (Derrida 1981a; 1997b). Whilst considering hospitality, there is a progression of thought in relation to 'ideals' and depiction of the 'other'; the preceding Derridean writings concerning depictions of maternity, gender, nature, community and family values in popular culture an 'ideal' version is considered impossible. With hospitality, Derrida stresses impossibility in a different way and makes an alternative use of the idea that ideals are impossible. This impossibility amounts to an 'otherness' with which there is an everyday relation. Derrida (1999a) quotes former French minister of immigration Michel Rocard who in 1993 stated, with respect to immigration quotas, that France could not offer a home to everybody in the world who suffered. Derrida (1999a) asserts that Rocard's immigration quota is set through mediation with a threshold of impossibility. For Derrida impossibility opens up possibilities of transformation, the case of Rocard highlighted the fragility of brutal authority. Some of the French 'hosts' might respond with quick agreement about the strict limitations on 'guests' however others might be provoked into asking why more and better hospitality should not be offered, and what does set the limit.

In considering hospitality more generally Derrida (1981a: 163) identifies 'otherness' in reference to "the other, the newcomer, the guest"; interrogating humanities ethical relationship with itself, receptiveness and in relationship with others: strangers; foreigners; immigrants; and friends - guests.

"For pure hospitality or a pure gift to occur, however, there must be an absolute surprise. The other, like the Messiah, must arrive whenever he or she wants. She (sic) may even not arrive. I would oppose, therefore, the traditional and religious concept of 'visitation' to 'invitation': visitation implies the arrival of someone who is not expected, who can show up at any time. If I am 
unconditionally hospitable I should welcome the visitation, not the invited guest, but the visitor. I must be unprepared, or prepared to be unprepared, for the unexpected arrival of any other. Is this possible? I don't know. If, however, there is pure hospitality, or a pure gift, it should consist in this opening without horizon, without horizon of expectation, an opening to the newcomer whoever that may be. It may be terrible because the newcomer may be a good person, or may be the devil" (Derrida 1998b:70)

This quote demonstrates an important distinction between messianicity and messianism', another way of reading his 'impossibility' and related notion of otherness. A messianism is considered by Derrida as a kind of dogmatism, subjecting the divine other to "metaphysico-religious determination" (Derrida 1994:89); forcing the ultimate guest, the Messiah, to conform or at least converge to the host's preconceptions of them. When imagining the coming of the Messiah the host attributes a new kind of origin and centrism to a divine other and assumes the latter suits their imaginative picture.

Faith for Derrida (1997a:120) is undeconstructible, while religion, like law, is deconstructible. Faith is "something that is presupposed by the most radical deconstructive gesture. You cannot address the other, speak to the other, without an act of faith, without testimony." To speak to another is to ask them to trust you.

"As soon as you address the other, as soon as you are open to the future, as soon as you have a temporal experience of waiting for the future, of waiting for someone to come; that is the opening of experience. Someone is to come, is now to come" (Derrida 1997a:123)

The faith in the other to come, according to Derrida, is absolutely universal, thus the universal structure of faith is an undeconstructible. In contrast, Derrida (2001b:67-8)

\footnotetext{
${ }^{1}$ Messianic structure or messianicity is the expectation of future coming of the Messiah and bringing of justice. Messianism is the identification in time and history of the messianic structure; messianisms say that the Messiah has already appeared in time, tradition, and history.
} 
suggests invoking messianicity: as "the unexpected surprise... If I could anticipate, if I had a horizon of anticipation, if I could see what is coming or who is coming, there would be no coming." Derrida's view of messianicity is not limited to a religious context, but extends to his depiction of otherness more generally. His comments about the other apply to a friend, someone culturally different, a parent, a child; where the issue arises of whether the host is capable of recognizing them, of respecting their difference, and of how the host may be surprised by them. Thus Derrida allows for a pure form of hospitality. However in the case of surprise the unsuspected guest is received on the terms of the host; unconditional hospitality is still impossible. Similarly when a country's borders are open to guests or immigrants, conditional hospitality places the country in relation to the impossible; the impossible greater generosity inhabits the act of conditional hospitality. Derrida's use of the host-guest relationship has influenced writers like Molz (2005) and Garcia and Crang (2005) to examine how the hospitality relationship influences host communities with their 'guests' immigrants, asylum seekers and refugees. Gibson (2005) explored the relationships between prisoners and their guards through the concept of hospitality.

Engaging with Derrida (2000), Rosello (2001) adopts a postcolonial philosophical stance, combines a brief historical inquiry into the nature of French hospitality as a metaphor for public acceptance of the other, and close textual analysis of several recent French and francophone novels and films; addressing what issues might be at stake if the immigrant (legal or otherwise, and usually non-European) were considered a guest. Examining France's traditional role as the terre d'asile (land of sanctuary) for political refugees, Rosello (2001) shows how this image of a 
welcoming France is now contrasted with France as part of the 'Fortress Europe' (a land that seeks to close its borders to unwelcome immigrants). Rosello's (2001) analysis also discusses the entire decade of the 1990s in France, when media reports of demonstrations and sit-ins by hundreds of sanspapiers (immigrants without papers) demanding amnesty and regularisation of their status, filled newspapers almost every week.

Rosello develops her stratification, of private concepts to public or state hospitality by examining the novel Un Aller Simple (One-Way Ticket). This novel, written by van Cauwelaert (1994), is a humorous story about a young man (born in France, raised by Gypsies) deported to a nonexistent Moroccan village because his fake passport names this fictional place as that of his birth. Rosello links this story to French and European Union immigration laws and treaties of the same decade (1990s). The absurdity of immigration laws that seek to reduce individuals to their official documentary identity, without regard to the fluctuating and ethereal nature of national identities are highlighted within the novel by van Cauwelaert. Rosello's textual analysis reveals different hospitality scenarios between groups and between individuals, especially the notion of hosts and guests and their respective responsibilities. Emphasising this Rosello (2000:176) notes:

"The very precondition of hospitality may require that, in some ways, both the host and the guest accept, in different ways, the uncomfortable and sometimes painful possibility of being changed by the other"

Within 'Fortress Europe' there does not seem to be the political will to allow increased immigration and the thought of European hosts being changed is an anathema. Rosello expresses grave concerns regarding the future of immigrants in Western Europe. It is unlikely that they be perceived of as honoured guests deserving 
of consideration, whereas it is more probable that they be likened to guests who have fallen into the category of parasite; they have overstayed their welcome and must be brutally ushered out.

Rosello's philosophical concerns are also reflected in the writings of another postcolonial theorist Tahar Ben Jalloun; a Moroccan who immigrated to France in 1971. Drawing upon his personal encounters with racism he uses the metaphor of hospitality to elucidate the racial divisions that plague contemporary France. Ben Jalloun (1999) states that laws of hospitality are a fundamental mark of civilisation, observing that he comes from a poor and relatively unsophisticated country, where the stranger's right to protection and shelter has been practiced since time immemorial. On moving to France, Ben Jalloun discovered that hospitality was not reciprocal, despite the benefits that France had clearly gained from her former colonies. Although France had enjoyed one side of the reciprocal arrangement, hospitality was not reciprocated to those who wished to come as guest to France; the former hosts were not welcomed as guests. Hospitality was conditional; a right to visit was not a right to stay. Ben Jalloun (1999:39) wishes to "open windows in the house of silence, indifference and fear", French society seems to remain inhospitable, even frightened by immigrants. Ben Jalloun (1999:116) suggests that former colonials feel abandoned by the authorities of their own countries and in France, live in fear of being returned to them: "in France he dreams of the country he left behind. In his own country, he dreams of France... he thumps back and forth a bag full of small possessions and of grand illusion". Despite having lived for about 30 years in France the author himself states that: 
"yet sometimes I feel I am a stranger here. That happens whenever racism occurs, whether it is virulent or latent, and whenever someone lays down limits that mustn't be transgressed" (Ben Jalloun 1999:133)

Ben Jalloun (1999) concludes with a plea aimed at policymakers, instead of laws that restrict hospitality, i.e. entry and residence, he advocates a policy that establishes links between morals and everyone's right to acceptance and equity.

For current postcolonial philosophical theory, hospitality is a multifaceted phenomenon. What are commonly referred to as 'laws of hospitality' are largely unwritten and thereby subject to flux and interpretation. For Rosello, what makes the phenomenon of hospitality relevant for philosophical investigation is the potential for redefinition in the traditional roles and duties of the guest and the host. Alternating between notions of duty and voluntary charity, hospitality between individuals and states of different racial, ethnic, or religious, backgrounds entails its own ramifications. Ben Jalloun (1999) argues that racism is caused by the existence of hospitality thresholds and boundaries.

\section{HOSPITALITY AND LANGUAGE}

The underlying principal is that during any hospitality relationship the host and guest inhabit the same moral universe and are subject to transcendent laws of hospitality. However the hospitality relationship is complicated by the use of language and culture. Ben Jelloun (1999:3) highlights the problem of language and cultural difference within different laws of hospitality:

"In an unpublished novella called 'The Invitation' I tell the true story of a television crew who went to Algeria to produce a program about an immigrant who had gone home. The shooting lasted a week, and throughout the whole time the villagers entertained the crew. The immigrant's father went into debt to provide presents and sumptuous meals all around. The director, touched by 
such warmth and generosity, gave the old man his business card. "If ever you're in Paris," he said in typical Parisian style, "be sure to come and see me!" But when one evening six months later the old man rang at his doorbell, it took the director some time to realize who he was. Very embarrassing for all concerned."

Ben Jelloun (1999:3) notes that this illustration shows "hospitality does not always imply reciprocity", however what this story also highlights is the embarrassment of the difference between expectations and behaviour. Both the guest and the host speak the same language, but are from different cultural backgrounds and their language and cultural differences led to confusion between how to extend and accept invitations.

Derrida (2000) proposes that issues of language cannot be dissociated from the most basic level of hospitality; guests can be discomforted and fundamentally disadvantaged by the host's language.

"The question of hospitality starts here: must we require the strange to understand us, to speak our language in all the meanings of the words, in all its possible extensions, before being able to, in order to be able to, welcome him or her" (Derrida 2000:21)

Derrida (2000c) argues that this imposition and use of language is the first barrier to hospitality that is imposed by the host on the guest. of violence that is inflicted on the guest by the host. Using Ancient Athens, Derrida (2000b:16) notes "the foreigner had some rights", the threshold of the host's domain establishes a social relation by delimiting the difference between those who are and are not of Athens. In the case of language, the social relations and understanding distinguish between sameness and difference; hospitality is extended on the host's terms and not those of the guest.

"Because intentionality is hospitality, it resists thematization. Act without activity, reason as receptivity, a sensible and rational experience of receiving, a gesture of welcoming, a welcome offered to the other as stranger, hospitality opens up as intentionality, but it cannot become an object, thing, or theme. Thematization, on the contrary, already presupposes hospitality, welcoming, 
intentionality, the face. The closing of the door, inhospitality, war, and allergy already imply, as their possibility, a hospitality offered or received: an original or, more precisely, pre-originary declaration of peace" $(1999,48)$

When M. Rocard closed the door on unconditional hospitality, Derrida (1999) argues that he opened up a conceptual paradox; similarly with this pre-originary hospitable declaration of peace there is another paradox at work. For the declaration to be understood, it has to be, a priori, inherently and universally understandable to everyone. This means, in turn, that a monolingual communication is required. In this situation Derrida (1998a) considers hospitality from the punitive side of what he refers to as a politics of language, within which monolinguism is imposed as a precondition for hospitality.

According to Derrida (1998a:10) monolinguism refers to a paradox that formed what he calls the rule of language:

"We only ever speak one language... (yes, but)

We never speak only one language."

Derrida was noticing in Ancient Athens where the foreigner was welcomed according to the duties and obligations that appropriate the foreigner in advance within Athenian law. This is a sovereign law that belongs to Athens, certainly, but that as in the case of all monolinguisms seem to originate from somewhere else, since even the native Athenians are always striving to appropriate it to themselves in the name of becoming the perfect and most native of citizens.

"First and foremost, the monolingualism of the other would be that sovereignty, that law originating from elsewhere, certainly, but also primarily the very language of the Law. Its experience would be ostensibly autonomous, because I have to speak this law and appropriate it in order to understand it as if I was giving it to myself, but it remains necessarily heteronomous, for such is, at bottom, the essence of any law. The madness of the law places its 
possibility lastingly inside the dwelling of this auto-heteronomy". (Derrida 1998b, 39)

Belonging to the monolinguism of a native tongue is difficult for the simple reason that this language is not entirely perfectible; therefore, there is always the slight sense of being a stranger or foreigner to it. This self-perception of being alien or foreign despite your native tongue or status is what Derrida calls auto-heteronomy. For Derrida the identification with the native tongue is important because being a native speaker is a sign of political identity and the consequential legal rights. Speaking a language, therefore, is a means of dwelling or remaining within a political identity even when you are a foreigner abroad.

The politics of language can protect, since it is politics that prepare the way for hospitality in the Athenian sense, in which citizens and foreigners are both known quantities with formal contractual relations of hosting and being a guest. However Derrida notes that the law under which people gather themselves to that language, gives them their political identity and security, is not as hospitable as one might like to imagine, precisely because it is political.

"[Language is] one of the numerous difficulties before us, as with settling the extension of the concept of hospitality... In the broad sense, the language in which the foreigner is addressed or in which he is heard, if he is, is the ensemble of culture, it is the values, the norms, the meanings that inhabit the language" (Derrida 2000:132)

In terms of language and hospitality this would mean that if language shelters the guest, it does not incorporate or assimilate the guest into itself. Derrida (1998a) notes that at the same time "we speak only one language..." because there is always the possibility of speaking otherwise, a speaking differently that is the condition of the essence of speaking one language properly. O'Gorman $(2005 ; 2007)$ shows that 
English is made up of different languages that, over time, have not only become incorporated into the native language but have been so incorporated as to become indistinguishable. This illustrates Derrida's observation that in speaking a single language it is impossible to speak one language alone. Derrida emphasises the difficulty of establishing a hard and fast difference between the native and the foreign.

\section{DISCUSSION AND CONCLUSIONS}

This paper has considered Derrida and other writers in order to review the current thinking of philosophers about hospitality. It presented three issues: moral philosophy of hospitality from the perspective of the guest host relationship; hospitality between peoples and nation states; and the use of language in hospitality provision and consumption. This separation, although artificial (because the distinctions are not entirely delimited), served as a useful way to gain an overview of the interrelated ideas. Discontentment and bias are two of the issues that arise from the writing of Derrida, Rosello and Ben Jelloun, it comes across clearly for example, in the writings of Ben Jelloun, in his homesickness and general discontent with his host country. Derrida too was an immigrant to France and his background could also have had a strong influence on his thinking and writing. This does not prove that either Derrida or Ben Jelloun have any political bias or underlying propagandist tendency; however the fact that neither of them seems to explicitly discuss their potential bias does leave room for doubt. In addition, in investigating the hospitality of the classical GrecoRoman world Derrida was then drawing conclusions and writing for the modern age. Telfer, through her treatment of domestic hospitality, and Derrida, Rosello and Ben Jelloun with their investigation of the state and the relationship to the individual, all to a greater or lesser extent seem to expect that the hospitality relationship should be the 
same. There is limited consideration given to the motivations of either the guest or the host, and even less recognition given to the fact that the hospitality relationship exists in dissimilar contexts: domestic, civic or commercial, each with their own different sets of laws.

For Derrida the hospitality given to the 'other' is an ethical marker, both for an individual and a country. Everyday engagement with the 'other' is fraught with difficulties; sometimes the 'other' is devalued or in extreme cases rejected. In the case of hospitality, the 'other' is often forced to take on the perceptions of the 'host'. The 'guests' are unable to be themselves; they must transform their 'otherness'. For Derrida, being open and accepting the 'other' on their terms opens the host to new experiences, what Pope John Paul II (1994:1) prophetically described as the possibility of "crossing thresholds of hope". Even when they have the true gift of hospitality is an act of generosity experienced by the 'guest', which turns a stranger into a friend for a limited period of time the best of intentions people fail in their attempts to behave hospitably and this adds to the complexity of the hospitality relationship:

We do not know what hospitality is.

Not yet.

Not yet, but will we ever know? (Derrida 2000b:6)

From Derrida's writings it seems that true hospitality is somewhat of an enigma. This is not due to any philosophical conundrum, but perhaps because hospitality is not a matter of objective knowledge. Hospitality exists within lived experience; it is a gift given by the 'host' to the 'guest', and then shared between them. Hospitality cannot be resolved on the pages of an academic journal; the true gift of hospitality is an act of 
generosity experienced by the 'guest', which turns a stranger into a friend for a limited period of time. 


\section{LIST OF REFERENCES}

Jacques Derrida's Obituary in The Economist October 21st 2004

Ben Jelloun, T. (1999) French Hospitality: Racism and North African Immigrants, Columbia University Press, New York.

Bennington, G. (1992) 'Mosaic fragment, if Derrida were an Egyptian' in Derrida: A Critical Reader. D Wood (ed) Blackwell, Massachusetts pp. 97 - 199.

Benveniste, E. (1969) Le Vocabulaire des Institutions Indo-européennes Éditions de Minuit, Paris.

Caputo, J.D. (2002) Deconstruction In A Nutshell: A conversation with Jacques Derrida. Fordham University Press, New York.

Derrida, J. (1973) Speech and Phenomena and Other Essays on Husserl's Theory of Signs. Northwestern University Press, Evanston

Derrida, J. (1976) Of Grammatology. Johns Hopkins University Press, Baltimore.

Derrida, J. (1978) Writing and Difference. Routledge, London.

Derrida, J. (1981) Dissemination. University of Chicago Press, Chicago.

Derrida, J. (1994) Specters of Marx: The State of the Debt, the Work of Mourning, and the New International. Routledge, New York.

Derrida, J. (1997a) The Villanova Roundtable: A Conversation with Jacques Derrida. In J.D. Caputo (ed) Deconstruction in a Nutshell: A Conversation with Jacques Derrida. Fordham U.P., USA.

Derrida, J. (1997b) Of Grammatology: Corrected edition. Johns Hopkins Press, Baltimore.

Derrida, J. (1998a) Monolinguism of the Other or the Prosthesis of Origin. Stanford University Press, Stanford.

Derrida, J. (1998b) Hospitality, Justice and Responsibility: A Dialogue with Jacques Derrida. In R. Kearney and M. Dooley (eds.) Questioning Ethics: Contemporary Debates in Philosophy. Roudedge, London.

Derrida, J. (1999a) Responsabilité et hospitalité. In M. Seffahi (ed) Manifeste pour l'hospitalité. Paroles l'Aube, Paris.

Derrida, J. (1999b) Sur Parole: Instantanés philosophiques. Editions de l'aube, Paris.

Derrida, J. (1999c) Adieu to Emmanuel Lévinas. Stanford University Press, Stanford.

Derrida, J. (2000a) 'Hostipitality', Angelaki: Journal of the Theoretical Humanities, Vol. 5 No. 3, pp 3-18.

Derrida, J. (2000b) Of Hospitality. Stanford University Press, Stanford.

Derrida, J. (2003) The Problem of Genesis in Husserl's Philosophy. University of Chicago Press, Chicago.

Deutscher, P. (2005) How to Read Derrida. Granta Books, London

Duval, M. (ed) (1984) CEuvres Complètes de Antoine Louis Leon De Saint Just 1767 1794. Gérard Lebovici, Paris.

Garcia, F. and Craing, P. (2005) Hospitality, the city, and the café culture:

Cosmopolitanism, conviviality and contemplation in Chueca, Madrid.

Conference Abstracts, Mobilising hospitality: the ethics of social relations in a mobile world. Lancaster University.

Gasché, R. (1986) The Tain in the Mirror. Harvard University Press, Cambridge.

Gibson, S. (2005) The hospitality industry: Hostility and inhospitableness in Britain.

Conference Abstracts, Mobilising hospitality: the ethics of social relations in a mobile world. Lancaster University. 
John Paul II (1994) Crossing the Threshold of Hope. Alfred A Knopf, London.

Lashley, C. (2004) Escaping the Tyranny of Relevance: some reflections on hospitality management education, paper presented at CAUTHE 2004, Alice Springs.

Lashley, C., Morrison, A., Lynch, P. (eds) Hospitality: A social lens. Elsevier: Oxford.

Morrison, A. and O'Gorman, K. (2006) Hospitality Studies: Liberating the Power of the Mind, paper presentation, CAUTHE2005, Victoria University, Melbourne.

Molz, J.G. (2005) Cosmopolitans on the Couch: Mobilising hospitality and the internet. Conference Abstracts, Mobilising hospitality: the ethics of social relations in a mobile world. Lancaster University.

Norris, C. (1987) Derrida. Fontana Modern Masters: London.

O'Gorman, K.D. (2005) Modern Hospitality: Lessons from the past, Journal of Hospitality and Tourism Management, 12, 2, 141-151.

O'Gorman, K.D. (2007) Dimensions of Hospitality: Exploring Ancient Origins. Hospitality: A social lens. Lashley, C., Morrison, A., Lynch, P. (eds) Elsevier: Oxford.

Rosello, M. (2001) Postcolonial Hospitality: The Immigrant as Guest. Stanford University Press, Stanford.

Rosello, M. (2002) European Hospitality without a home: Gypsy communities and illegal immigration in Van Cauwelaert's Un Aller simple. Studies in 20th Century Literature Vol. 26 No. 1 pp. 172-93

Rorty, R. (1982) Consequences of Pragmatism. University of Minnesota Press, Princeton.

Schérer, R. (1993) Zeus Hospitalier: Eloge de l'hospitalité. Armand Colin, Paris.

Stocker, B. (2006) Derrida on Deconstruction. (Routledge, London)

Telfer, E. (1996) Food for Thought, Philosophy of Food. Routledge, London.

Telfer, E. (2000) The Philosophy of hospitableness in C. Lashley, and A. Morrison, (eds.) In Search of Hospitality - Theoretical Perspectives and Debates. (Butterworth Heinemann, Oxford)

Wahnich, S. (1997a) L'impossible Citoyen: L'étranger dans le discours de la révolution française. Albin Michel, Paris.

Wahnich, S. (1997b) L'hospitalité et la Révolution française. In D. Fassin, A. Morice, and C. Quirninal (eds), Les lois de l'inhospitalité: Les politiques de l'immigration à l'épreuve des sans-papiers. La Découverte, Paris.

\footnotetext{
${ }^{\mathrm{i}}$ A French institution that specialises in training academics, it provides a high proportion of French university lecturers.
} 